\title{
Biogenic Synthesis of Silver Chloride Nanoparticles from Padina gymnospora and their Evaluation of Antimicrobial, Larvicidal, Hemolytic and Anticancer Activities.
}

\section{Gopalan Rajagopal}

Ayya Nadar Janaki Ammal College

Nandhagopal Manivannan

University of Madras

Sundararajan Mahalingam

University of Missouri Health Care

Krishnan Anand

University of the Free State

Samuthirarajan Senthilkumar

Jiaxing University

Narayanasamy Mathivanan

University of Madras - Guindy Campus

Naresh Kumar Katari

GITAM University

\section{Samson Sitheni Mashele}

Central University of Technology Free State

Muthupandian Saravanan ( $\sim$ saravanan.muthupandian@mu.edu.et)

Mekelle University College of Health Sciences https://orcid.org/0000-0002-1480-3555

Sakkanan llango

Ayya Nadar Janaki Ammal College

\section{Research}

Keywords: Padina gymnospora, Silver chloride nanoparticles, Human breast cancer, Aedes aegypti, antimicrobial, larvicidal, Cytotoxicity, Flow cytometry

Posted Date: May 13th, 2020

DOI: https://doi.org/10.21203/rs.3.rs-24840/v1 
License: (c) (i) This work is licensed under a Creative Commons Attribution 4.0 International License. Read Full License 


\section{Abstract}

In the current study, silver chloride nanoparticles (AgCINPs) have been synthesized using the aqueous extract of Padina gymnospora and further characterized by Uv-visible spectroscopy, Fourier-transform infrared spectroscopy, X-ray powder diffraction, Scanning electron microscopy, energy dispersive spectroscopy, Transmission electron microscopy and Atomic force microscopy. The synthesized silver chloride nanoparticles were found to be mono-dispersed and spherical with an average size between 11.5 to $32.86 \mathrm{~nm}$. The particles also showed a cytotoxic effect in a dose-dependent manner against MCF 7 cells $\left(\mathrm{IC}_{50}=31.37 \mu \mathrm{g} / \mathrm{mL}\right)$. Besides, it showed the larvicidal activity against Aedes aegypti at a lower dose $(3.92 \mu \mathrm{g} / \mathrm{ml})$ than that of the aqueous extract $(13.01 \mu \mathrm{g} / \mathrm{ml})$. It also exhibited significant antimicrobial activity against selected bacterial and fungal pathogens. The synthesized silver chloride nanoparticles showed the best minimum inhibitory concentration (MIC) of $8 \mathrm{mg} / \mathrm{L}$ in Canadian Albicans, followed by vancomycin resistance Enterococcus feacasli (VREF) $32 \mathrm{mg} / \mathrm{L}$. Furthermore, the toxicity assessment by haemolytic assay revealed that AgCINPs could be safe and also used for further investigation. Therefore, the synthesized silver chloride nanoparticles may be used as a therapeutic agent for breast cancer, antimicrobial agent and also to control the dengue vector as attributed to the presence of bioactive components.

\section{Introduction}

Nanotechnology plays a diverse role in medical sciences and pharmaceutical industries in recent years [1]. In connection with that, evolving nano-based therapeutics has received substantial attention over the last two decades [2-5]. Researchers are tried to design the synthesis of nanoparticles for various applications which include therapeutics and diagnostics purposes, based on their cellular mechanisms and the advanced technology in nanomaterials [1]. Besides, silver-based nanoparticles have received more attention, due to their enhanced properties of physio-chemical and biological characteristics based upon the preparation of the nanoparticles by using additional elements [6]. Silver ions can inhibit bacterial multiplication by binding and denaturing bacterial DNA, thus affecting the ribosomal subunit protein and some enzymes inevitable for bacterial cell growth by penetrating the cells $[7,8]$. Most of the silver nanoparticles are used as anticancer [9-11], antimicrobial agents [6, 12,13] and also have been reported for many biomedical applications [14]. The fusion of silver nanoparticles with natural resources is observed as an eco-friendly and cost-effective approach that bounces progressively over the other physico-chemical methods.

In the middle of associated silver materials, silver chloride plays an essential role in the application of wound healing, antimicrobial and also acts as a preservative of drinking water for long term storage in the tank [15-17]. Silver chloride nanoparticles (AgCINPs) also have various fields of photochemical and biomedical applications such as fabricating antiseptic catheters, bone cement, and fabrics owing to the antibacterial activity [18]. Despite these advantages, AgCINPs preparation is limited in a few ways such as micro-emulsion technique, ultrasound irradiation, matrix-based technique or mixing silver nitrate 
$\left(\mathrm{AgNO}_{3}\right)$ with hydrochloride acid in the presence of poly (vinyl pyrrolidone) for tuning its properties and applications [6].

Several protocols have been reported for AgCINPs synthesis using microorganisms such as bacteria, fungi and algae [6] [19]. To this extent, very few reports were available under the criteria of the synthesis of AgClNPs from marine resources and their application in the medicinal field [20]. The present work involves the synthesis of AgCINPs using the marine algae, P. gymnospora and its applications in the biomedical field have been investigated.

Padina gymnospora is a marine algae which belong to the family Dictyotacaea. It has a morphology of brown and darker at the base and the fan-shaped lobe has split into wedge-shaped pieces. It is used as a prominent natural wound-care product [21]. In the present study, it was initiated to explore the application of green synthesized AgCINPs by using seaweed P. gymnospora (Pg-AgCINPs) in the medical application of anticancer, antibacterial and larvicidal activity. In addition to that, the toxicity effect of $P g$-AgCINPs was assessed.

\section{Materials And Methods}

\subsection{Plant Materials and Chemicals}

Seaweeds (Padina gymnospora) collected from Gulf of Mannar region, Tuticorin located $\left(8.76^{\circ} 42^{\prime \prime} \mathrm{N}\right.$; $\left.78.13^{\circ} 48^{\prime \prime} \mathrm{E}\right)$ at the Southeast coast of India by handpicking and rinsing immediately with water to take away all kinds of epiphytes and other impurities (i.e., sand, molluscs, seagrasses, etc.). Then they were packed into sterilized Ziploc bags and transferred to the laboratory. Silver nitrate, cell culture medium, trypsin, and FBS were procured from HiMedia, Mumbai, India. Other chemicals/reagents used in this study were purchased from HiMedia, Mumbai, India.

\subsection{Preparation of seaweed extract}

The collected algae were cleaned with de-ionized water and allowed to shade dry up to seven days, and they were made into powder form using a blender. For the seaweed extraction, ten grams of algal powder was added into every three Erlenmeyer flasks containing $100 \mathrm{ml}$ of double distilled water and mixed well and kept for 5 hrs without disturbance. Then they filtered through Whatman No. 1 filter paper. The filtrates were used for the synthesis of AgNP for larvicidal activity against Ae. aegypti.

\subsection{Synthesis of AgNP from seaweed extract}

For AgNP synthesis, silver nitrate is used as a precursor. The $\mathrm{AgNO}_{3}$ and extracts of $P$. gymnospora were selected for the production of green synthesis nanoparticles. Previously, $\mathrm{AgNO}_{3}(1 \mathrm{mM})$ dissolved in distilled water $(100 \mathrm{ml})$. The extract of $P$. gymnospora was added to $\mathrm{AgNO}_{3}$ solution in 2:10 ratio, and the solution was incubated in a dark room and used for analysis. After reduction, the incubated solution centrifuged at $10,000 \mathrm{rpm}$ for $15 \mathrm{~min}$ at $4{ }^{\circ} \mathrm{C}$ and three repeated wash with double distilled water was performed to discard a clear supernatant solution. 


\subsection{Physico-chemical characterization of AgCINPs}

\subsubsection{UV-Vis Spectra}

The colour change was observed in the silver nitrate solution incubated with aqueous extract of $P$. gymnospora. The bioreduction of $\mathrm{AgNO}_{3}$ ions in solution was monitored by periodic sampling of aliquots $(0.1 \mathrm{~mL})$ of aqueous components and measuring the UV-vis spectra of the solution in 10-mm-opticalpath-length quartz cuvettes with an UV-1601 (Shimadzu, International, Co. Ltd, Tokyo, Japan) spectrophotometer at a resolution of $1 \mathrm{~nm}$ between 400 and $800 \mathrm{~nm}$ with a scanning speed of $1,856 \mathrm{~nm} / \mathrm{min}$.

\subsubsection{XRD analysis}

The XRD analysis was carried out to analyze the crystallite size of Pg-AgCINPs by the biological method. Samples for powder X-ray Diffraction (XRD) were prepared by making a thin film of powder with ethanol on a glass plate, and the measurement was performed using an Ultima IV - Rigaku diffractometer with CuKa radiation ( $\lambda=1.540 \AA, 45 \mathrm{kV}$ and $30 \mathrm{~mA})$ Tokyo, Japan.

\subsubsection{FT-IR analysis}

FTIR analysis was performed using an FTIR-8400S spectrometer (Shimadzu, International, Co. Ltd, Tokyo, Japan) spectrophotometer to verify possible interaction of chemical bonds between bio-molecules of seaweed and silver nitrate solution. Samples were scanned from $400-4000 \mathrm{~cm}^{-1}$ with potassium bromide pellets. Characteristic peaks of plain Pg-AgCINPs, seaweed extract and are expressed in a reciprocal wavelength $\left(\mathrm{cm}^{-1}\right)$.

\subsubsection{TEM analysis}

Conventional TEM analysis was performed in a High-Resolution Transmission Electron Microscope (HRTEM - JEOL-2100 + JEOL India Pvt. Ltd., New Delhi. India) using a magnification of 46000x. The samples were prepared by the formvar resin grid method. Briefly, a $0.5 \% \mathrm{w} / \mathrm{v}$ suspension of prepared $\mathrm{Pg}$-AgClNPs was sprayed onto a formvar resin-coated TEM grid and air-dried for 10 minutes before observation. The morphology of Pg-AgCINPs complexes was photographed.

\subsubsection{SEM and EDX analysis}

For morphological characteristics, the Pg-AgClNPs were uniformly spread and sputter-coated with platinum using an ion coater for $120 \mathrm{~s}$, and then observed under an SEM EV018-CARL ZEISS, USA. EDX is a technique used for identifying the elemental composition of the specimen or an area of interest thereof, and the system works as an integrated feature of the SEM which was done by using Quantax 200 with XFlash ${ }^{\circledR}$ 6130. Bruker India Scientific Pvt. Ltd. Bangalore, India.

\subsubsection{AFM analysis}

A thin film of the sample was prepared on a coverslip by dropping $0.1 \mathrm{ml}$ of the sample on the slide and allowed to dry for $30 \mathrm{~min}$. The slides were then scanned with AFM (Park system XE-100 AFM system, 
Suwon, Korea). The AFM characterization was carried out in ambient temperature in non-contact mode using silicon nitrate tips with varying resonance frequencies.

\subsection{Anti-proliferative effects}

\subsubsection{MTT-based cytotoxicity assay}

The cytotoxic effects of compounds against human tumour cell lines were determined by a rapid colourimetric assay, using 3-(4, 5-dimethylthiazol-2-yl)-2, 5-diphenyl tetrazolium bromide (MTT) and compared with untreated controls. For screening experiments, the cells were seeded in 96-well plates in $100 \mu \mathrm{L}$ of medium containing $5 \% \mathrm{FBS}$, at plating density 10,000 cells/well and incubated at $37^{\circ} \mathrm{C}, 5 \%$ $\mathrm{CO}_{2}, 95 \%$ air and relative humidity (100\%) for $48 \mathrm{~h}$ prior to addition of compounds. After $48 \mathrm{~h}$, compounds at various concentrations were added and incubated at $37^{\circ} \mathrm{C}, 5 \% \mathrm{CO}_{2}, 95 \%$ air and relative humidity (100\%) at $48 \mathrm{~h}$. Triplicate was maintained, and the medium without the sample was served as control [22].

\subsubsection{Assessment of cell death through Flow cytometry}

Flow cytometry study was carried out using propidium iodide staining. Breast cancer cell line MCF 7 was seeded in 6 wells with microtiter plates. After $24 \mathrm{~h}$, the medium was discarded, and the calculated concentration of the compound was added to each well and incubated for $48 \mathrm{~h}$ at $37^{\circ} \mathrm{C}$. Cells were washed with PBS several times and trypsinized. The cells were then suspended in $1 \mathrm{~mL}$ of PBS and centrifuged at $1000 \mathrm{rpm}$ for $3 \mathrm{~min}$. The supernatant was discarded, and the pellet obtained was vortexed at a lower speed. Then, $1 \mathrm{~mL}$ of PBS was added again and centrifuged at $1000 \mathrm{rpm}$ for $6 \mathrm{~min}$. The supernatant was discarded, and the pellet was suspended in $250 \mu \mathrm{L}$ of PBS. The obtained cell suspension was stored in $0.8 \mathrm{~mL}$ of ethanol and incubated at $4{ }^{\circ} \mathrm{C}$ for $30 \mathrm{~min}$. To the sample, $10 \mu \mathrm{L}$ of propidium iodide was added and incubated at room temperature for $30 \mathrm{~min}$ and protected from light (BD, Sasc, Jazz Trademark, US).

\subsection{Mosquito rearing}

The egg rafts of Ae. aegypti obtained from the Vector Control Research Centre, Madurai, Tamil Nadu India. Larvae of $A$. aegypti reared in enamel trays containing dechlorinated water. The larvae are fed with a finely powdered mixture having a 3:1 ratio of dark biscuits and dry yeast. The larvae were observed and monitored for III instar stages, and it was used for the larvicidal activity.

\subsubsection{Larvicidal activity}

The toxic activity of different concentrations $(2,4,6.8$ and $10 \mu \mathrm{g} / \mathrm{ml})$ of $P g$-AgClNPs was evaluated against the III instar of $A$. aegypti. The aqueous extract of $P$. gymnospora was tested against various concentrations $(5,10,20,30$, and $60 \mu \mathrm{g} / \mathrm{ml})$ against the larvae. Mortality recorded after 24 and $48 \mathrm{hrs}$ of post-exposure [23]. The results obtained were subjected to statistical analysis. The dose-dependent response data were concerned with probit analysis for finding the $\mathrm{LC}_{50}$, upper, and lower confidence limit at $95 \%$ [24]. 


\subsection{Anti-microbial activity}

The antimicrobial activity of $P g$-AgCINPs was done by the well diffusion (or) Kirby-Bauer method in Muller-Hinton Agar (MHA) medium. The sterilized MHA medium at $121^{\circ} \mathrm{C}$ at $15 \mathrm{lbs}$ for 20 min was poured into sterile Petri plates, allowed to solidify, and the pathogens were swabbed using a sterile cotton swab over the surface of the medium. After 15 min the wells were made using cork-borer on agar medium. The Pg-AgClNPs were loaded at three different concentrations dissolved in 50\% Dimethyl sulfoxide (DMSO) $1 \mathrm{mg} / \mathrm{mL}, 2 \mathrm{mg} / \mathrm{mL}$ and $3 \mathrm{mg} / \mathrm{mL}$ as stock solution $100 \mu \mathrm{l}$ each concentration was loaded at three different wells. Zone of inhibition was measured after 24 hrs of incubation at $37^{\circ} \mathrm{C}$.

\subsection{Minimum Inhibitory Concentration (MIC) of synthesized nanoparticles}

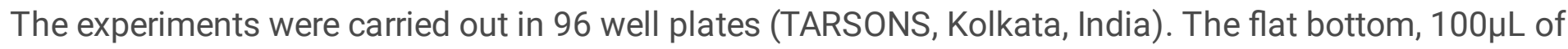
sterilized Muller-Hinton Broth was loaded in all the test wells. The synthesized nanoparticles and commercially available antibiotics were diluted 512, 256, 128, 64, 32, 16, 8, 4, 2, 1 mg/L. For positive control taken in ten wells, the 11th well for negative control (without organism) and 12th well for test pathogens as $5 \mu \mathrm{L}$, The 12 hrs grown in MHB broth at concentrations of $10^{5}$ to $10^{6} \mathrm{CFU} / \mathrm{mL}$ were added to all the wells except negative control. The plates were incubated at $37^{\circ} \mathrm{C}$ for $16 \mathrm{hrs}$. After incubation $10 \mu \mathrm{L}$ of $5 \mathrm{mg} / \mathrm{mL}$ concentration, freshly prepared MTT (3-(4,5-Dimethylthiazol-2-yl)-2,5-Diphenyltetrazolium Bromide) was added to all the wells and incubated for $10 \mathrm{~min} .100 \mu \mathrm{L}$ of DMSO solution was added as the solubilizing agent and incubated for 15 minutes. Optical density (OD) was taken at $595 \mathrm{~nm}$, the percentage of cell death was calculated, and MIC was noted.

\subsection{Hemolytic assay}

The hemolytic activity of Pg-AgClNPs was determined in fresh anti-coagulated human blood cells. The cells were washed twice with phosphate-buffered saline (PBS) and diluted at $10 \%$ of concentration, $800 \mu \mathrm{L}$ of nanoparticles diluted at the concentrations of $100,50,25,12.5,6.25,3.12,1.56,0.78 \mu \mathrm{g} / \mathrm{mL}$ in phosphate-buffered saline solution at micro-centrifuge tubes. Negative control as PBS and positive control 1\% Triton X-100, $200 \mu \mathrm{L}$ of Red Blood Cell (RBC) suspension added all tubes incubated for $1 \mathrm{hrs}$ at $37^{\circ} \mathrm{C}$. All treated tubes centrifuged at $2000 \mathrm{rpm}$ for $5 \mathrm{~min}$ and supernatants were transferred to the new 96-well microtiter test plate, and absorbance read at $540 \mathrm{~nm}$. The amount of haemoglobin released was calculated using negative control (no hemolysis) and Triton X-100 (positive control, complete hemolysis).

The percentage of hemolysis was calculated as $\left[\left(A_{540}, N P S-A_{540}, P B S\right) /\right.$

$\left(\mathrm{A}_{540}, 1 \%\right.$ Triton $\left.\left.\mathrm{x}-100-\mathrm{A}_{540}, \mathrm{PBS}\right)\right] \times 100$.

\subsection{Statistical Analysis}

One-way analysis of variance (ANOVA) followed by a Tukey post-hoc test was used for MTT analysis. Probit analysis followed by Finney method. These statistical analyses were performed using the 
Statistical Package for the Social Sciences 16.0 package in Chicago, USA. Data were presented as mean $\pm S D$ and $P$ values $<0.05$ was considered to be statistically significant.

\section{Result And Discussion}

Initially, the formation of green synthesized $P g$-AgClNPs was visually identified by the appearance of dark brown colour in $24 \mathrm{hrs}$ of incubation (P. gymnospora with silver nitrate) (Fig. 1). The colour change from pale yellow to dark brown clearly indicating the formation of silver chloride nanoparticles. Then it was optically confirmed by UV-spectrophotometric analysis. A strong surface plasmon resonance peak was obtained around $377 \mathrm{~nm}$ (Fig. 2), which indicates the formation of AgCINPs [25, 26]. The maximum absorbance indicates the relative size of the nanoparticle, where the higher number corresponds to a larger particle size [27]. The chloride ions present in the seaweed extract converts $\mathrm{AgNO}_{3}$ to $\mathrm{AgClNPs}$. Thus the chlorine content of the extracts could be the source for the formation of AgCINPs [28, 29]. The chlorine ions in the seaweed extracts were confirmed by EDAX Analysis. It reveals the presence of silver (56.6\%) and chloride (22.9\%) along with other elements such as B, C, O, Na, and Si was found to be contributed by the bioorganic materials present in the seaweed extract bound to the nanoparticle surface (Fig. 3).

The FTIR spectrum of P. gymnospora (Fig. 4a) shows that the strong bands observed at 1100, 1137 and $1416 \mathrm{~cm}^{-1}$ are assigned to $-\mathrm{C}-\mathrm{O},-\mathrm{C}=\mathrm{O}$ and $-\mathrm{C}=\mathrm{C}$ stretching of aromatic acids and esters present in the seaweed extract respectively. The band at $1643 \mathrm{~cm}^{-1}$ is attributed to $-\mathrm{C}=0$ stretching of amides. The sharp bands at 2307,3399 and $3727 \mathrm{~cm}^{-1}$ correspond to $\mathrm{NH}$ stretching vibrations of primary and secondary amines in the crude extract. In the fingerprint region, the peaks observed at 601 and $676 \mathrm{~cm}^{-1}$ correspond to the presence of $\mathrm{C}-\mathrm{Cl}$ groups in the seaweed extract. These functional groups could act as biomolecules for stabilizing, capping and reducing agents for the formation of AgCINPs. On the other hand, the IR spectrum of $P g$-AgCINPs shows the peaks of $-\mathrm{C}-0$ stretching shifted from $1100 \mathrm{~cm}^{-1}$ to $1088 \mathrm{~cm}^{-1}$ and the peak of $\mathrm{N}-\mathrm{H}$ stretching shifted from $3399 \mathrm{~cm}^{-1}$ to $3142 \mathrm{~cm}^{-1}$ (Fig. $4 \mathrm{~b}$ ). It reveals that the carboxylic and amine groups are involved in the stabilization and immobilization of AgCINPs in the seaweed extract. The role of $-\mathrm{C}=\mathrm{C}$ in the reduction of silver salt is evident by the peak observed at $1392 \mathrm{~cm}^{-1}$ which was found at $1416 \mathrm{~cm}^{-1}$ in seaweed extract respectively. Further, the presence of peaks at $1633 \mathrm{~cm}^{-1}$ confirms the amide stretching group. The sharp peak observed at $594 \mathrm{~cm}^{-1}$ confirms the presence of $\mathrm{AgCl}$ NPs stabilised by the seaweed P. gymnospora extract.

The powder XRD analysis of synthesized Pg-AgCINPs (Fig. 5) exhibits the crystalline structure with diffraction peaks obtained at $27.87^{\circ}, 32.35^{\circ}, 46.20^{\circ}, 54.45^{\circ}, 57.45^{\circ}$ and $67.49^{\circ}$ corresponds to the planes of (111), (200), (220), (311), (222) and (400) respectively which matches with the standard JCPDS File No. 85-1355. There is no other peak indicating that the high purity of prepared $\mathrm{Pg}$-AgClNPs and the strong intensity of the peak shows a high crystallinity of the sample. The grain size was calculated as $30.39 \mathrm{~nm}$ using Scherrer's formula. The absence of additional reflection indicates that Pg-AgCINP's lattice was not affected by other molecules in seaweed extract. SEM micrographs showed that the synthesized 
nanoparticles were observed with fine spherical crystals (Fig. 6) and the morphological features obtained from TEM reveal that the $P g$-AgCINPs are mono-dispersed spherical shape with the average particle size of around $33 \mathrm{~nm}$ (Fig. 7). AFM micrographs indicate that the formulated Pg-AgCINPs possess a spherical shape and the calculated sizes in the range of 15.5 to $21.38 \mathrm{~nm}$ (Fig. 8). It characterizes the interactions between the $\mathrm{Pg}$-AgCINPs and the supported lipid bilayers in real-time. The particle size is varied from 10 to $28 \mathrm{~nm}$.

The $P g$-AgCINPs were evaluated for anticancer activity against breast cancer cell line (MCF-7 cell line), and the cytotoxicity to the normal (Vero) cell line was also studied. Pg-AgCINPs showed a cytotoxic effect on breast cancer cells in a dose-dependent manner. The $\mathrm{IC}_{50}$ values of $\mathrm{Pg}$-AgCINPs against breast cancer cells were found $31.37 \mu \mathrm{g} / \mathrm{mL}$ for MCF-7 and $421.46 \mu \mathrm{g} / \mathrm{mL}$ for Vero Cells (non-tumor cells) (Fig. 9). In vitro cell viability assay clearly revealed that $P g$-AgCINPs were severely toxic to human breast cancer cells even more than AgNPs (data not shown). Interestingly, the synthesized Pg-AgCINPs have lower cytotoxicity effect on Vero non-tumour derived cell line. Growth inhibition related to cell cycle arrest and apoptosis was determined in flow cytometry using propidium iodide. MCF7 cell lines were treated with $\mathrm{IC}_{50}$ concentration of compounds. MCF7 cells treated with $\mathrm{IC}_{50}$ concentration of compounds increased the percentage of apoptosis in G0-G1 phase (5.16\% when compared with control of $1.39 \%$ ). An increase in the percentage of apoptotic cells was measured by flow cytometry, clearly clarifying an induction of programmed cell death in the cancer cells after treatment with AgCINPs. The Pg-AgCINPs induce cell death through the mitochondrial pathway. Most of the studies reported that AgNP's mediated cell death is independent of p53 [30] $[12,13]$. Previously, it was reported that the biosynthesis of AgClNPs induces the cytotoxicity and apoptosis effect on human breast cancer cells through the up-regulation of apoptotic factors [6].

The larval bioassays performed by aqueous extracts of $P$. gymnospora and Pg-AgClNPs against larvae of Aedes agypti are a dengue vector. For the extract of $P$. gymnospora showed $\mathrm{LC}_{50}$ of $34.92 \mu \mathrm{g} / \mathrm{ml}$ in $24 \mathrm{hrs}$ and $21.61 \mu \mathrm{g} / \mathrm{ml}$ in $48 \mathrm{hrs}$ and $11.82 \mu \mathrm{g} / \mathrm{ml}$ in $72 \mathrm{hrs}$. While the synthesized $P g$-AgClNPs show LC $_{50}$ and $\mathrm{LC}_{90}$ of $7.15 \mu \mathrm{g} / \mathrm{ml}$ in $24 \mathrm{hrs}, 6.06 \mu \mathrm{g} / \mathrm{ml}$, in $48 \mathrm{hrs}$ and $3.61 \mu \mathrm{g} / \mathrm{ml}$ in $72 \mathrm{hrs}$ (Table 1). Among them, the $P g$-AgCINPs showed higher larvicidal activity against $A$. aegypti with low concentration compared to the aqueous extract of $P$. gymnospora. The toxicity mechanisms of mosquito mortality in the nanoparticle treatment were studied recently. It is hypothetically suggested that the mechanism of toxicity against mosquito larvae by the penetration of nanoparticles through the exoskeleton. In intracellular space, nanoparticle degrades the enzymes and organelles, and it leads to the loss of cellular function and cell death [31, 32]. The AgNPs from Artemisia vulgaris leaf extracts showed the mosquito larvicidal activity. By the accumulation of nanoparticles in the midgut region of mosquito, larva causes damage in the midgut, cortex region, and epithelial cells. Similar to seaweed mediated synthesis of nanoparticles, several plants mediated synthesized nanoparticles were shown in mosquito larval control [33]. 
Table 1

The larval bioassays performed by aqueous extract of $P$. gymnospora and green synthesized silver chloride nanoparticle

\begin{tabular}{|c|c|c|c|c|c|c|c|}
\hline \multirow[t]{2}{*}{ Sample } & \multirow{2}{*}{$\begin{array}{l}\text { Conc } \\
(\mu \mathrm{g} / \mathrm{ml})\end{array}$} & Exposure & $\mathrm{LC}_{50}$ & $\mathrm{LC}_{90}$ & \multirow[t]{2}{*}{ Intercept } & \multirow{2}{*}{$\begin{array}{l}\mathrm{X}^{2} \\
\text { Value }\end{array}$} & \multirow[t]{2}{*}{ pValue } \\
\hline & & Time(hr) & 95\%LCL-UCL & 95\%LCL-UCL & & & \\
\hline \multirow[t]{5}{*}{$\begin{array}{l}\text { Crude } \\
\text { Extract }\end{array}$} & \multirow{3}{*}{$\begin{array}{l}5 \\
10\end{array}$} & 24 & $\begin{array}{l}34.92(29.69 \\
+4395)\end{array}$ & $\begin{array}{l}61.73(50.46 \\
+86.43)\end{array}$ & -1.67 & 3.75 & 0.99 \\
\hline & & & & & & & \\
\hline & & 48 & $\begin{array}{l}21.61(17.48 \\
\pm 25.91)\end{array}$ & $\begin{array}{l}44.87(37.98 \\
\pm 57.59)\end{array}$ & -1.19 & 6.90 & 0.90 \\
\hline & \multirow{2}{*}{30} & 72 & $11.82(7.19$ & 31.02 (26.18 & -0.79 & 4.25 & 0.98 \\
\hline & & & $\pm 15.35)$ & & & & \\
\hline \multirow[t]{4}{*}{ Pg-AgCINPs } & 2 & 24 & $\begin{array}{l}7.15(6.30+ \\
8.16)\end{array}$ & $\begin{array}{l}11.99(10.44 \\
+14.86)\end{array}$ & -1.89 & 2.84 & 0.99 \\
\hline & 6 & 48 & $\begin{array}{l}6.06(5.19 \pm \\
6.95)\end{array}$ & $\begin{array}{l}10.88(9.49 \\
+13.36)\end{array}$ & -1.61 & 6.19 & 0.93 \\
\hline & \multirow[b]{2}{*}{10} & 72 & $3.61(2.49 \pm$ & $7.82(6.81 \pm$ & -1.10 & 5.79 & 0.95 \\
\hline & & & & & & & \\
\hline
\end{tabular}

AgClNPs act as an alternative source for microbial pathogens. The green synthesized Pg-AgClNPs were assessed for the antimicrobial activity against the human pathogens. Pg-AgCINPs showed antimicrobial activity in a dose-dependent manner. They were reported in Table 2. Compared to pathogenic bacteria and fungi, it acts as a good antifungal activity (Fig. 11). Moreover, the MIC also investigated these microbes by using $P g$-AgClNPs at the range of $1 \mathrm{mg} / \mathrm{mL}$ by the serial dilution method. They were reported in Table 3. Among all concentrations of the selected pathogens, Canadian Albicans showed the best minimum inhibition at the concentrations of $8 \mathrm{mg} / \mathrm{L}$, followed by VREF $32 \mathrm{mg} / \mathrm{L}$. AgNPs act as an alternative source for microbial pathogens. Due to different variations and great impact on antimicrobial properties, it was predominately used in pharmaceuticals and drug industries [34]. Pg-AgCINPs showed antimicrobial activity in a dose-dependent manner. Compared to pathogenic bacteria and fungi, it acts as a good antifungal activity. Microbial growth inhibition in AgNPs is due to the surface and particle size variance [35]. The possible mechanism of antimicrobial activity is because of the generation of free radicals. The AgNPs interact with bacteria and release the $\mathrm{Ag}^{+}$ions inside the cell as leads to cells leaked out caused by protein denaturation [36, 37]. The small size of AgNPs has a larger surface area, facilitates the interaction with the bacterial cell membrane, and altered the primary function of the cell membrane, including permeability and cell respiration, causing cell apoptosis [38]. Previous studies reported that the bacterial cells treated with AgCINPs caused the morphological changes and that AgCINPs were distributed on the surface of the bacterial cells [29]. 
Table 2

Antimicrobial activity of Green synthesized silver chloride nanoparticle compound against human pathogens

\begin{tabular}{|llllll|}
\hline \multirow{2}{*}{$\begin{array}{l}\text { Concentration } \\
(\mathrm{mg} / \mathrm{mL})\end{array}$} & \multicolumn{4}{l}{ Zone of Inhibition $(\mathrm{mm})$} \\
\cline { 2 - 6 } & \multicolumn{2}{l}{ Gram-positive bacterium } & \multicolumn{2}{l|}{ Gram-negative bacterium } & Fungal Pathogen \\
\cline { 2 - 6 } & MRSA & VREF & E. coli & P. aeruginosa & C. albicans \\
\hline 1 & 22 & 26 & 14 & 19 & 29 \\
\hline 2 & 22 & 26 & 14 & 21 & 31 \\
\hline 3 & 23 & 27 & 15 & 22 & 31 \\
\hline
\end{tabular}

Table 3

Minimum Inhibitory Concentration of MIC Green synthesized silver chloride nanoparticle.

\begin{tabular}{|c|c|c|c|c|c|c|c|c|c|c|}
\hline \multirow{4}{*}{$\begin{array}{l}\text { Nano- } \\
\text { Particles }\end{array}$} & \multicolumn{10}{|c|}{ Minimum inhibitory concentration (MIC) (mg/L) } \\
\hline & \multicolumn{4}{|c|}{ Gram-positive bacterium } & \multicolumn{4}{|c|}{ Gram-negative bacterium } & \multirow{2}{*}{\multicolumn{2}{|c|}{$\begin{array}{l}\text { Fungal Pathogen } \\
\text { C. albicans }\end{array}$}} \\
\hline & \multicolumn{2}{|c|}{ MRSA } & \multicolumn{2}{|c|}{ VREF } & \multicolumn{2}{|c|}{ E. coli } & \multicolumn{2}{|c|}{ P. aeruginosa } & & \\
\hline & NP & PC & NP & PC & NP & PC & NP & PC & NP & PC \\
\hline MIC value & 64 & 4 & 32 & 1 & 128 & 1 & 64 & 2 & 8 & NA \\
\hline \multicolumn{11}{|c|}{$\begin{array}{l}\text { MRSA: Methicilline resistance Staphylococcus aureus; VREF: Vancomycine resistance Enterococcus } \\
\text { feacalis }\end{array}$} \\
\hline
\end{tabular}

Hemolytic activity of synthesized silver nanoparticles was screened at different concentrations among them. Pg-AgCINPs particles showed the hemolytic activity in $100 \mu \mathrm{g} / \mathrm{mL} 92 \%$ followed by $50 \mu \mathrm{g} / \mathrm{mL} 12 \%$ of hemolysis from the $25 \mu \mathrm{g} / \mathrm{ml}$ concentration showed no hemolysis to the human blood cells (Table 4). This result suggests that $P g$-AgClNPs can be safe and also used for further investigation (Fig. 12). At the nanotoxicity level, the investigation on blood compatibility is essential because the blood cells are affected by nanoparticles directly or indirectly. The erythrocytes circulate to various organs through the cardiovascular system leading to DNA damage, cell membrane injury, and congenital malformation $[7,8]$. In this condition, the biocompatibility of AgNPs rupturing and releasing of erythrocytes have more attention to analyzing the toxicity level of nanoproducts [34].

\section{Conclusion}

The active principle of AgCINPs obtained from the seaweed $P$. gymnopora exhibits potent anticancer activity against MCF 7 cells, and it also has a larvicidal activity against the $A$. aegypti as compared to the aqueous extract of $P$. gymnopora without harming the non-target organism. AgCINPs also exhibits antimicrobial activity and biocompatibility to RBC in connection with human welfare. Overall, the 
synthesis of $P g$-AgClNPs is considered as eco-toxic and eco-friendly. It can be effectively used against breast cancer cells. In addition, it controls the $A$. aegypti dengue causes vector disease, and it may also be used as an antimicrobial agent against the human infectious pathogen.

\section{Declarations}

\section{ACKNOWLEDGEMENT}

We are grateful for the management and principal of the Ayya Nadar Janaki Ammal College, Sivakasi for providing good laboratory facilities.

\section{Funding}

Not Applicable

\section{Contributions}

GR and SI conceived and designed the study, GR, NM, SM, KA,SS, and NM, Synthesis and

Characterization, GR,NKK,SSM, MS and SI performed Biomedical application Nanoparticles; GR,NKK,SSM, MS and SI analyzed the data; SI, NM, MS and KA provided advice and technical assistance; and GR,SI, KA and MS wrote the manuscript. All authors read and approved the final manuscript.

\section{Availability of data and materials}

All data generated or analyzed during this study are included in this published article.

\section{Ethics declarations}

Ethics approval and consent to participate

Not applicable.

\section{Consent for publication}

All authors agree to be published.

\section{Conflicts of interests}

All authors declared no conflict of interest.

\section{References}


1. Baskar G, Chandhuru J, Fahad KS, Praveen A, Chamundeeswari M, Muthukumar T. Anticancer activity of fungal L-asparaginase conjugated with zinc oxide nanoparticles. Journal of Materials Science: Materials in Medicine. 2015;26:43.

2. Bhattacharyya S, Kudgus RA, Bhattacharya R, Mukherjee P. Inorganic nanoparticles in cancer therapy. Pharmaceutical research. 2011;28:237-59.

3. Boisselier E, Astruc D. Gold nanoparticles in nanomedicine: preparations, imaging, diagnostics, therapies and toxicity. Chemical society reviews. 2009;38:1759-82.

4. Asgary V, Shoari A, Afshar Moayad M, Shafiee Ardestani M, Bigdeli R, Ghazizadeh L, Khosravy MS, Panahnejad E, Janani A, Bashar R. Evaluation of G2 citric acid-based dendrimer as an adjuvant in veterinary rabies vaccine. Viral immunology. 2018;31:47-54.

5. Sadat Shandiz SA, Shafiee Ardestani M, Shahbazzadeh D, Assadi A, Ahangari Cohan R, Asgary V, Salehi S. Novel imatinib-loaded silver nanoparticles for enhanced apoptosis of human breast cancer MCF-7 cells. Artificial cells nanomedicine biotechnology. 2017;45:1082-91.

6. Bigdeli R, Shahnazari M, Panahnejad E, Cohan RA, Dashbolaghi A, Asgary V. Cytotoxic and apoptotic properties of silver chloride nanoparticles synthesized using Escherichia coli cell-free supernatant on human breast cancer MCF 7 cell line. Artificial cells nanomedicine biotechnology. 2019;47:1603-9.

7. AshaRani P, Low Kah Mun G, Hande MP, Valiyaveettil S. Cytotoxicity and genotoxicity of silver nanoparticles in human cells. ACS Nano. 2008;3:279-90.

8. Foldbjerg R, Dang DA, Autrup H. Cytotoxicity and genotoxicity of silver nanoparticles in the human lung cancer cell line, A549. Arch Toxicol. 2011;85:743-50.

9. Hanan NA, Chiu HI, Ramachandran MR, Tung WH, Zain M, Nadhirah N, Yahaya N, Lim V. Cytotoxicity of plant-mediated synthesis of metallic nanoparticles: a systematic review. Int J Mol Sci. 2018;19:17-25.

10. De Matteis V, Cascione M, Toma CC, Leporatti S. Silver nanoparticles: Synthetic routes, in vitro toxicity and theranostic applications for cancer disease. Nanomaterials. 2018;8:319.

11. Sriram MI, Kanth SBM, Kalishwaralal K, Gurunathan S. Antitumor activity of silver nanoparticles in Dalton's lymphoma ascites tumor model. Int J Nanomed. 2010;5:753.

12. Tang S, Zheng J. Antibacterial activity of silver nanoparticles: structural effects. Advanced healthcare materials. 2018;7:1701503.

13. Yun'an Qing LC, Li R, Liu G, Zhang Y, Tang X, Wang J, Liu H, Qin Y. Potential antibacterial mechanism of silver nanoparticles and the optimization of orthopedic implants by advanced modification technologies. Int J Nanomed. 2018;13:3311.

14. Asgary V, Shoari A, Baghbani-Arani F, Shandiz SAS, Khosravy MS, Janani A, Bigdeli R, Bashar R, Cohan RA. Green synthesis and evaluation of silver nanoparticles as adjuvant in rabies veterinary vaccine. Int J Nanomed. 2016;11:3597.

15. Li L, Zhu Y-J. High chemical reactivity of silver nanoparticles toward hydrochloric acid. J Colloid Interface Sci. 2006;303:415-8. 
16. Choi M, Shin K-H, Jang J. Plasmonic photocatalytic system using silver chloride/silver nanostructures under visible light. J Colloid Interface Sci. 2010;341:83-7.

17. Bai J, Li Y, Li M, Wang S, Zhang C, Yang Q. Electrospinning method for the preparation of silver chloride nanoparticles in PVP nanofiber. Appl Surf Sci. 2008;254:4520-3.

18. Paladini F, Pollini M, Sannino A, Ambrosio LJB. Metal-based antibacterial substrates for biomedical applications. 2015, 16:1873-1885.

19. Singh V, Rawat KS, Mishra S, Baghel T, Fatima S, John AA, Kalleti N, Singh D, Nazir A, Rath SKJJoMCB. Biocompatible fluorescent carbon quantum dots prepared from beetroot extract for in vivo live imaging in C. elegans and BALB/c mice. 2018, 6:3366-3371.

20. Dhas TS, Kumar VG, Karthick V, Angel KJ, Govindaraju KJSAPAM, Spectroscopy B. Facile synthesis of silver chloride nanoparticles using marine alga and its antibacterial efficacy. 2014, 120:416-420.

21. Baliano AP, Pimentel EF, Buzin AR, Vieira TZ, Romão W, Tose LV, Lenz D, de Andrade TU, Fronza M, Kondratyuk TP. Brown seaweed Padina gymnospora is a prominent natural wound-care product. Revista Brasileira de Farmacognosia. 2016;26:714-9.

22. Mosmann T. Rapid colorimetric assay for cellular growth and survival: application to proliferation and cytotoxicity assays. J Immunol Methods. 1983;65:55-63.

23. Organization WH. Instructions for determining the susceptibility or resistance of mosquito larvae to insecticides. Geneva: World Health Organization; 1981.

24. Finney DJ. Probit analysis: a statistical treatment of the sigmoid response curve. Cambridge: Cambridge university press; 1952.

25. Youn M-H, Lim Y-M, Gwon H-J, Park J-S, An S-J, Nho Y-C. Characterization of an antibacterial silver chloride/poly (acrylic acid) deodorant prepared by a gamma-ray irradiation. Macromol Res. 2009;17:813-6.

26. Kang Y, Jung J-Y, Cho D, Kwon O, Cheon J, Park W. Antimicrobial silver chloride nanoparticles stabilized with chitosan oligomer for the healing of burns. Materials. 2016;9:215.

27. Saion E, Gharibshahi E, Naghavi K. Size-controlled and optical properties of monodispersed silver nanoparticles synthesized by the radiolytic reduction method. Int J Mol Sci. 2013;14:7880-96.

28. Gopinath V, Priyadarshini S, Priyadharsshini NM, Pandian K, Velusamy P. Biogenic synthesis of antibacterial silver chloride nanoparticles using leaf extracts of Cissus quadrangularis Linn. Mater Lett. 2013;91:224-7.

29. Dhas TS, Kumar VG, Karthick V, Angel KJ, Govindaraju K. Facile synthesis of silver chloride nanoparticles using marine alga and its antibacterial efficacy. Spectrochim Acta Part A Mol Biomol Spectrosc. 2014;120:416-20.

30. Anand T, Sundararajan M, Anbukkarasi M, Thomas PA, Geraldine P. A Methanolic Extract of Ocimum basilicum Exhibits Antioxidant Effects and Prevents Selenite-induced Cataract Formation in Cultured Lenses of Wistar Rats. Pharmacognosy Journal 2019, 11. 
31. Sowndarya P, Ramkumar G, Shivakumar M. Green synthesis of selenium nanoparticles conjugated Clausena dentata plant leaf extract and their insecticidal potential against mosquito vectors. Artificial cells nanomedicine biotechnology. 2017;45:1490-5.

32. Yazhiniprabha M, Vaseeharan B, Sonawane A, Behera A. In vitro and In vivo toxicity assessment of phytofabricated $\mathrm{ZnO}$ nanoparticles showing bacteriostatic effect and larvicidal efficacy against Culex quinquefasciatus. J Photochem Photobiol B. 2019;192:158-69.

33. Sharma A, Kumar S, Tripathi P. A facile and rapid method for green synthesis of Achyranthes aspera stem extract-mediated silver nano-composites with cidal potential against Aedes aegypti L. Saudi Journal of Biological Sciences 2017.

34. Parthiban E, Manivannan N, Ramanibai R, Mathivanan N. Green synthesis of silver-nanoparticles from Annona reticulata leaves aqueous extract and its mosquito larvicidal and anti-microbial activity on human pathogens. Biotechnology Reports. 2019;21:e00297.

35. Song H, Ko K, Oh I, Lee B. Fabrication of silver nanoparticles and their antimicrobial mechanisms. Eur Cells Mater. 2006;11:58.

36. Cui J, Liang Y, Yang D, Liu Y. Facile fabrication of rice husk based silicon dioxide nanospheres loaded with silver nanoparticles as a rice antibacterial agent. Scientific reports. 2016;6:21423.

37. Morones JR, Elechiguerra JL, Camacho A, Holt K, Kouri JB, Ramírez JT, Yacaman MJ. The bactericidal effect of silver nanoparticles. Nanotechnology. 2005;16:2346.

38. Panáček A, Kvitek L, Prucek R, Kolář M, Večeřová R, Pizúrová N, Sharma VK, Nevěčná $T$, Zbořil R. Silver colloid nanoparticles: synthesis, characterization, and their antibacterial activity. J Phys Chem B. 2006;110:16248-53.

\section{Figures}



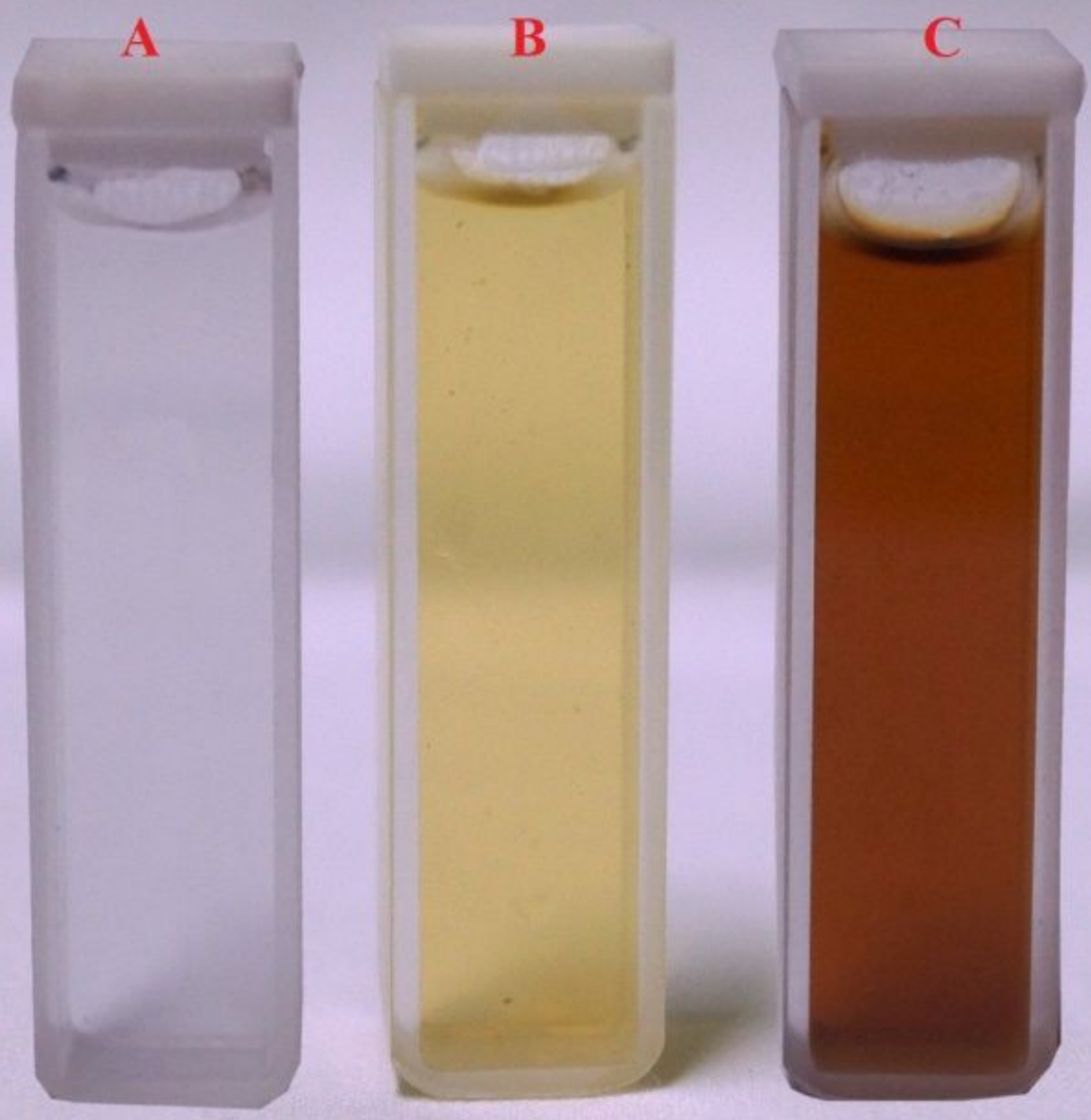

\section{Figure 1}

Green Synthesis of Silver Chloride Nanoparticles from Padina gymnospora. The colour changes from yellow to brown. A - AgNo3 solution. B - P. gymnospora Extract. C - Pg-AgCINPs 


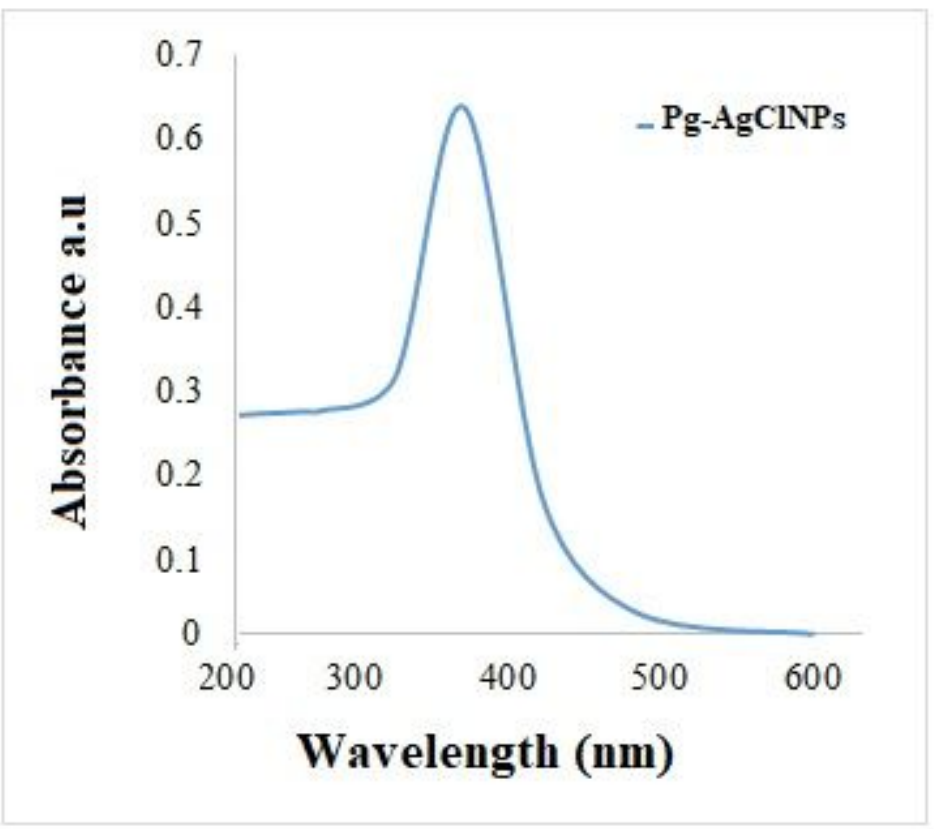

Figure 2

UV Spectrometric analysis of Pg-AgCINPs. The highest peak value observed at the range of $377 \mathrm{~nm}$ 


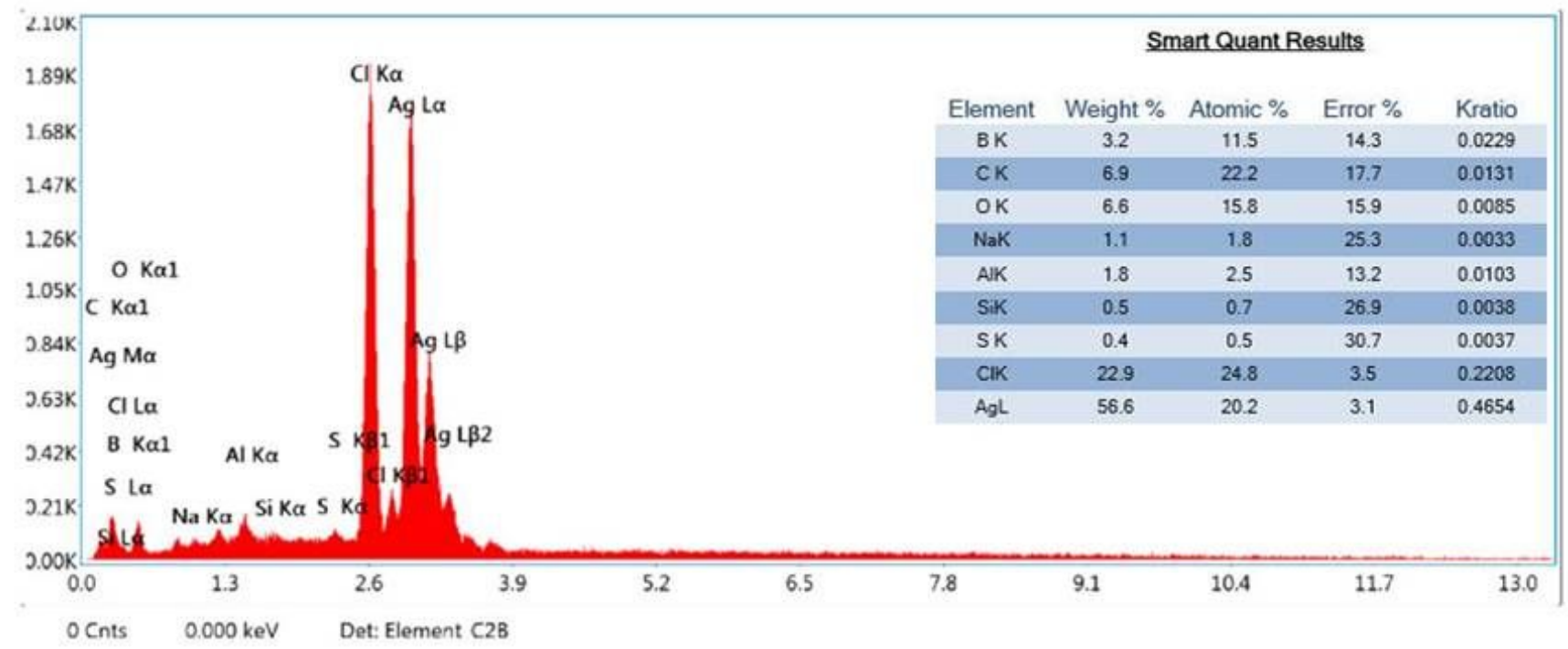

Figure 3

EDAX analysis of Pg-AgCINPs. EDAX analysis reveals the signal for silver (56.6\%) along with signals of other elements $\mathrm{B}, \mathrm{C}, \mathrm{O}, \mathrm{Na}, \mathrm{Si}$, and $\mathrm{Cl}$ 


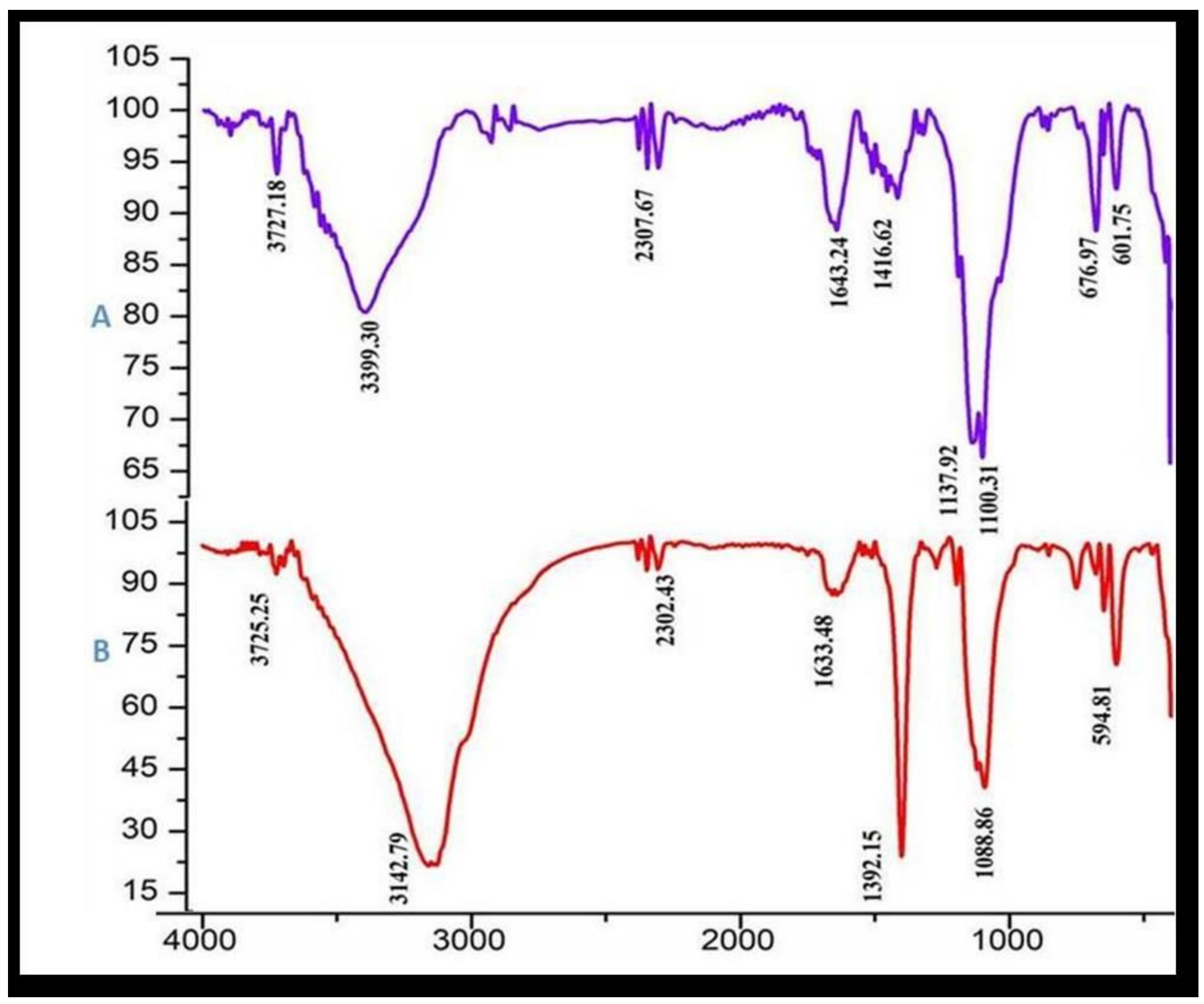

Figure 4

(a): FTIR analysis of the aqueous extract of P.gymnospora. The presence of the amine group and alcohol group in P. gymnospora (b): FTIR analysis of Pg-AgCINPS. It reveals the presence of functional groups such as alcohol, amines, amides, methyl, alkanes, halides and aliphatic compounds. 


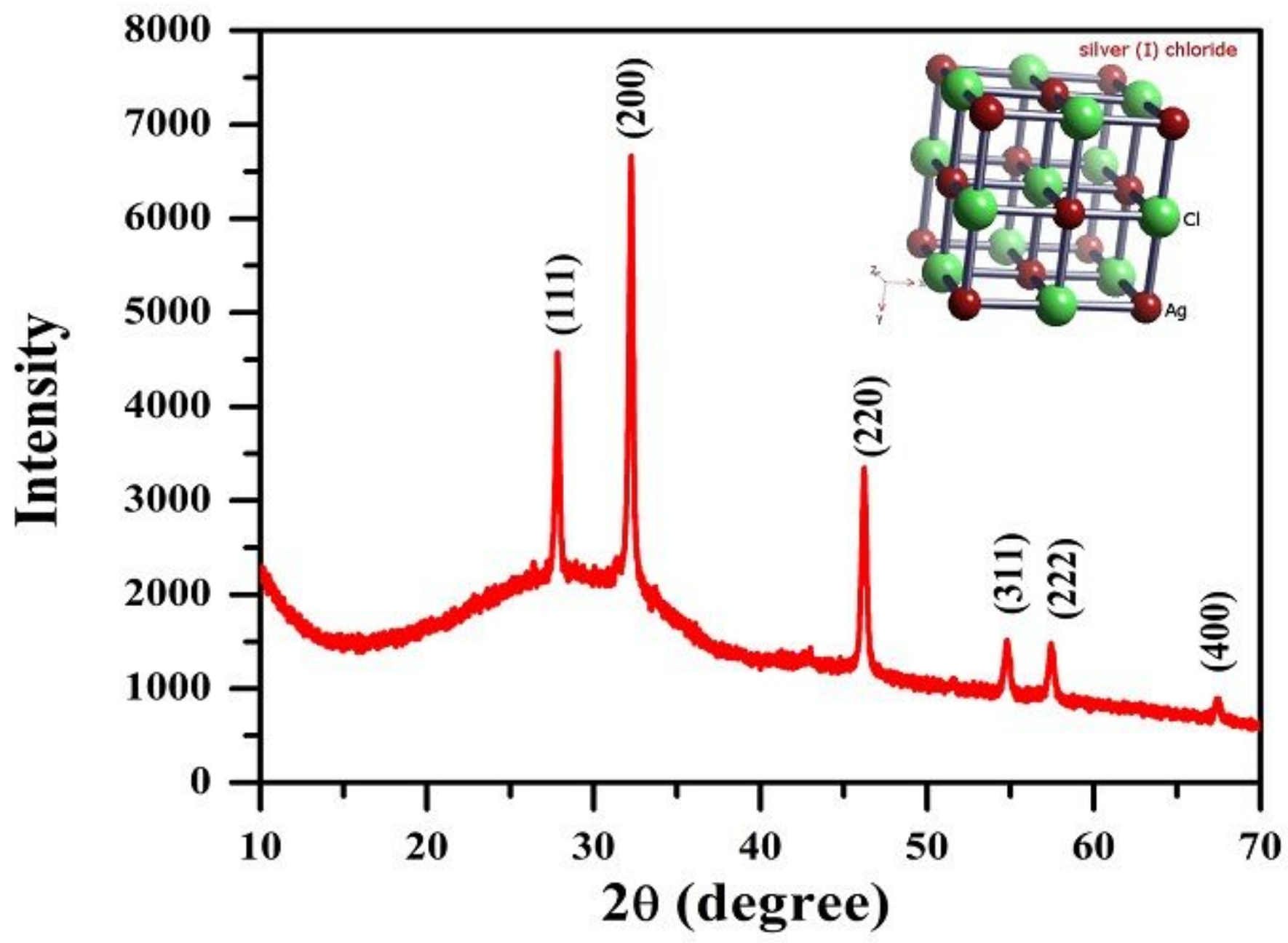

Figure 5

XRD analysis of Pg-AgCINPs. It shows five strong intense peaks corresponding to 27.55, 28.46, 31.05, 40.63 and 41.78 teta as Face-centered cubic Pg-AgCINPs (JCPDS file no. 85-1355) confirms the identity of the synthesized nanoparticle grain size $30.39 \mathrm{~nm}$. 


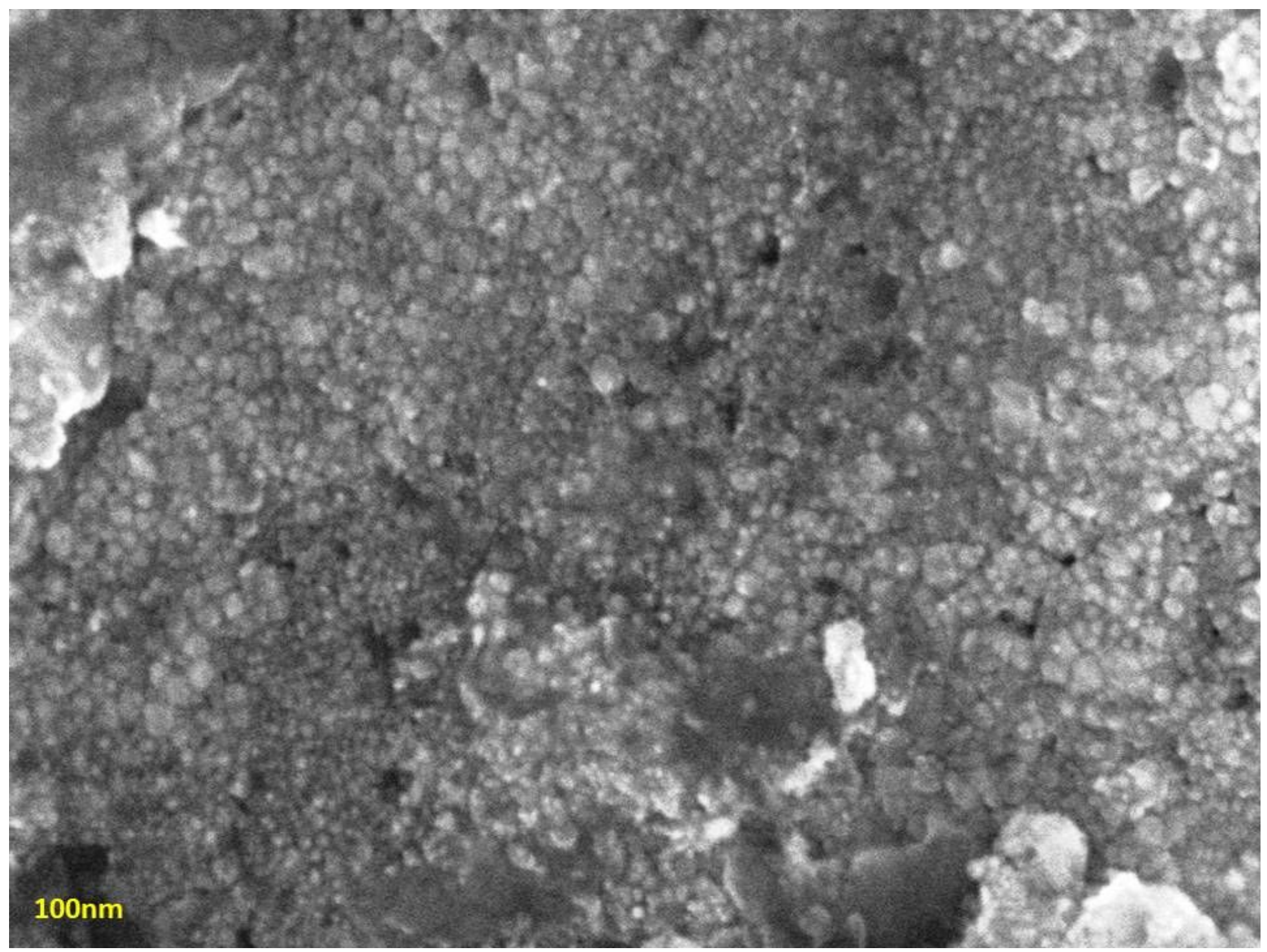

\section{Figure 6}

SEM analysis of Pg-AgCINPs. The nanoparticle was observed to be round like structure and occurred in monodispersed. 


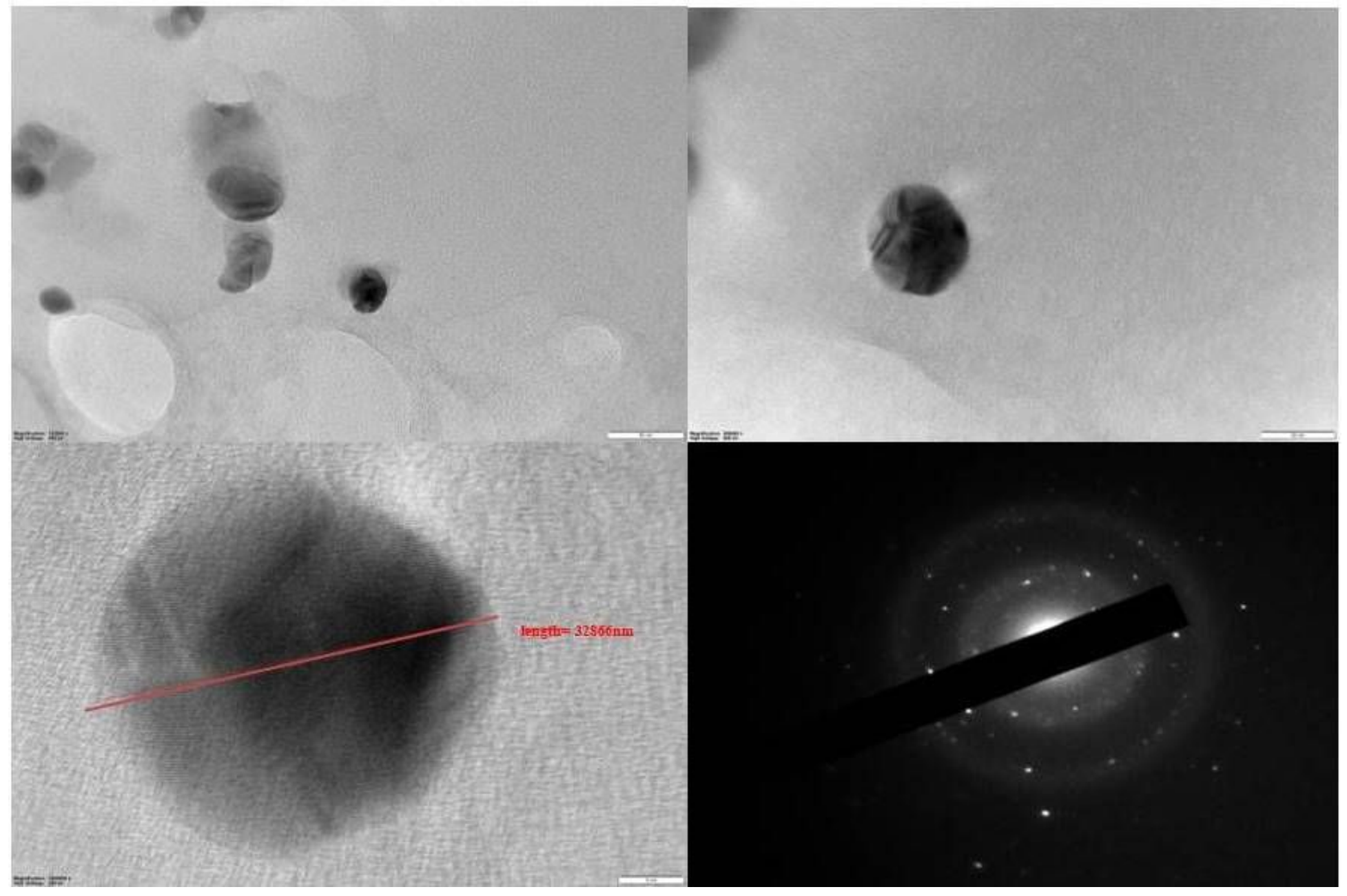

\section{Figure 7}

TEM analysis of Pg-AgCLINPs. TEM micrograph showed that the presence of mono-dispersed spherical shape of nanoparticles was the average size of $32.866 \mathrm{~nm}$. 

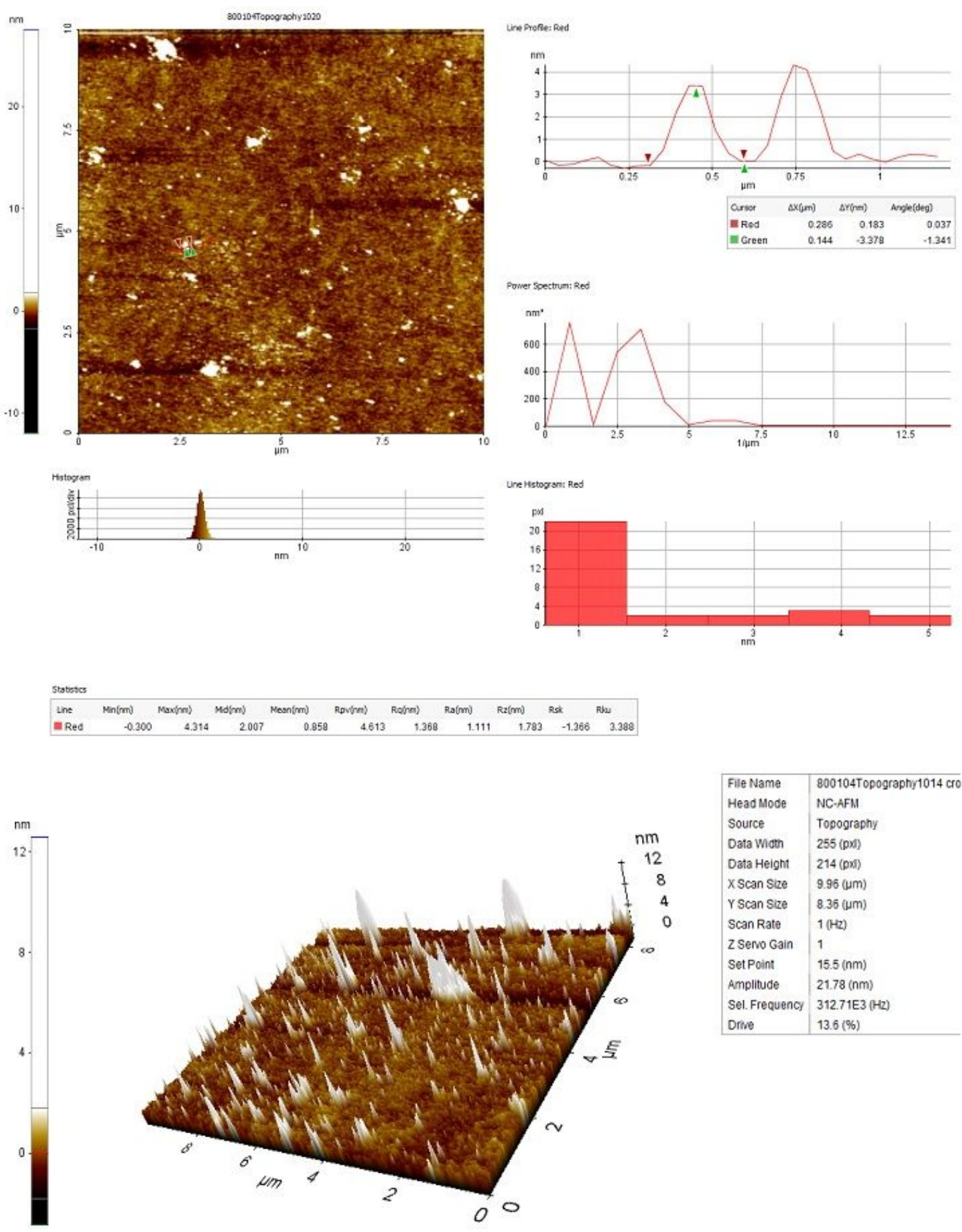

Figure 8

AFM analysis of Pg-AgClNPs. The obtained micrographs indicate that the formulated Pg-Ag NPs possess a round shape and the calculated sizes in the range of 15.5 to $21.78 \mathrm{~nm}$. 


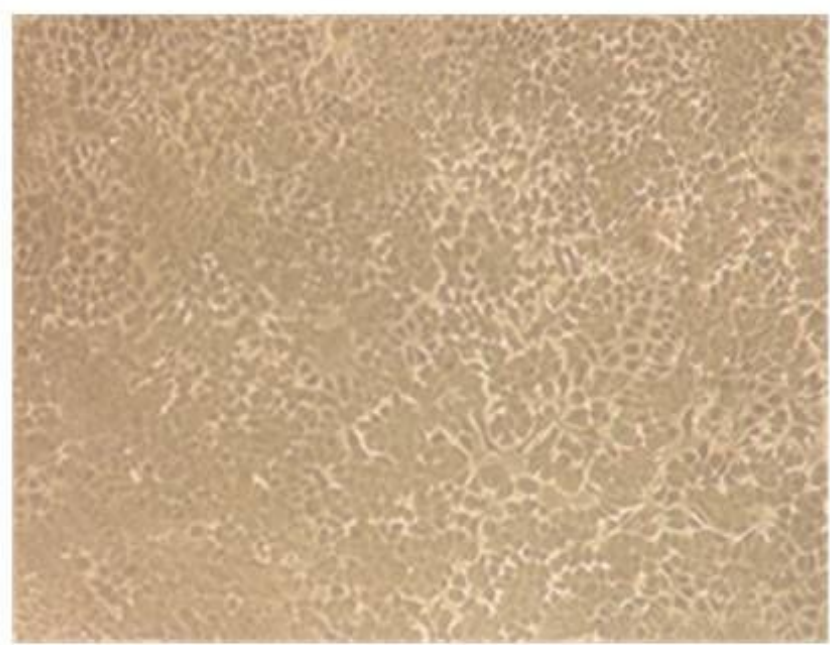

MCF7 Control

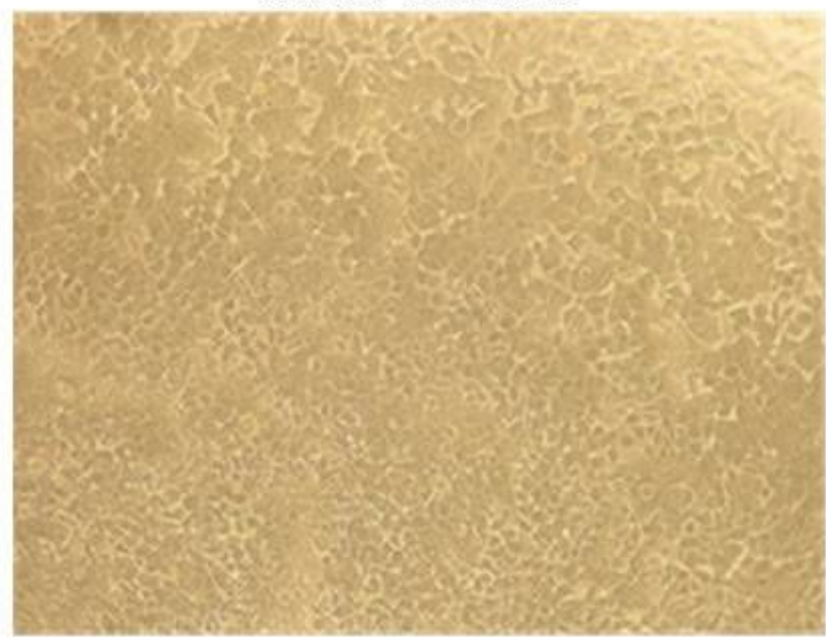

Vero Cell Control

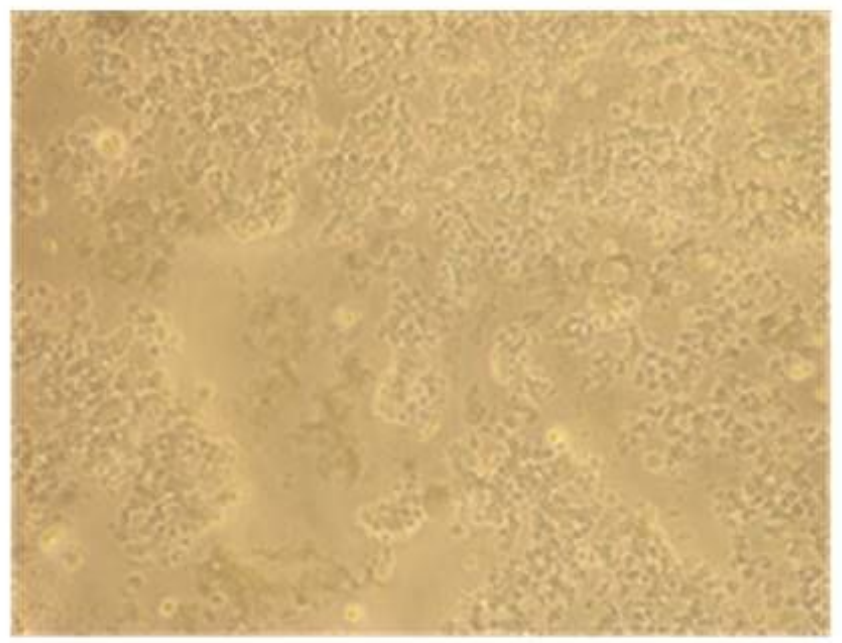

MCF7 Treated $P g$-AgCINPs

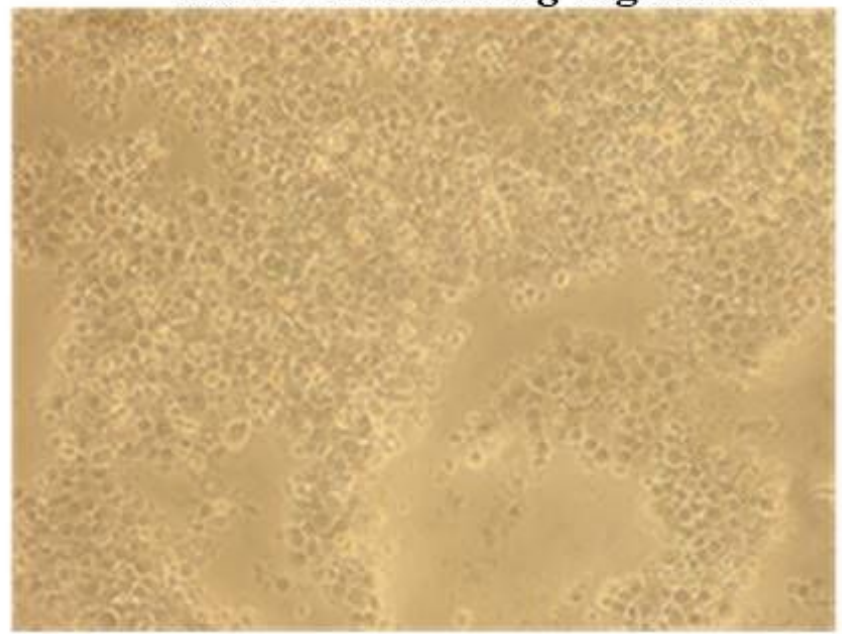

Vero Treated $P g$-AgCINPs

\section{Figure 9}

The IC50 values of Pg-AgCINPs against breast cancer cells were found $31.37 \mu \mathrm{g} / \mathrm{mL}$ for MCF-7 and $421.46 \mu \mathrm{g} / \mathrm{mL}$ for Vero Cells (non-tumor cells). 


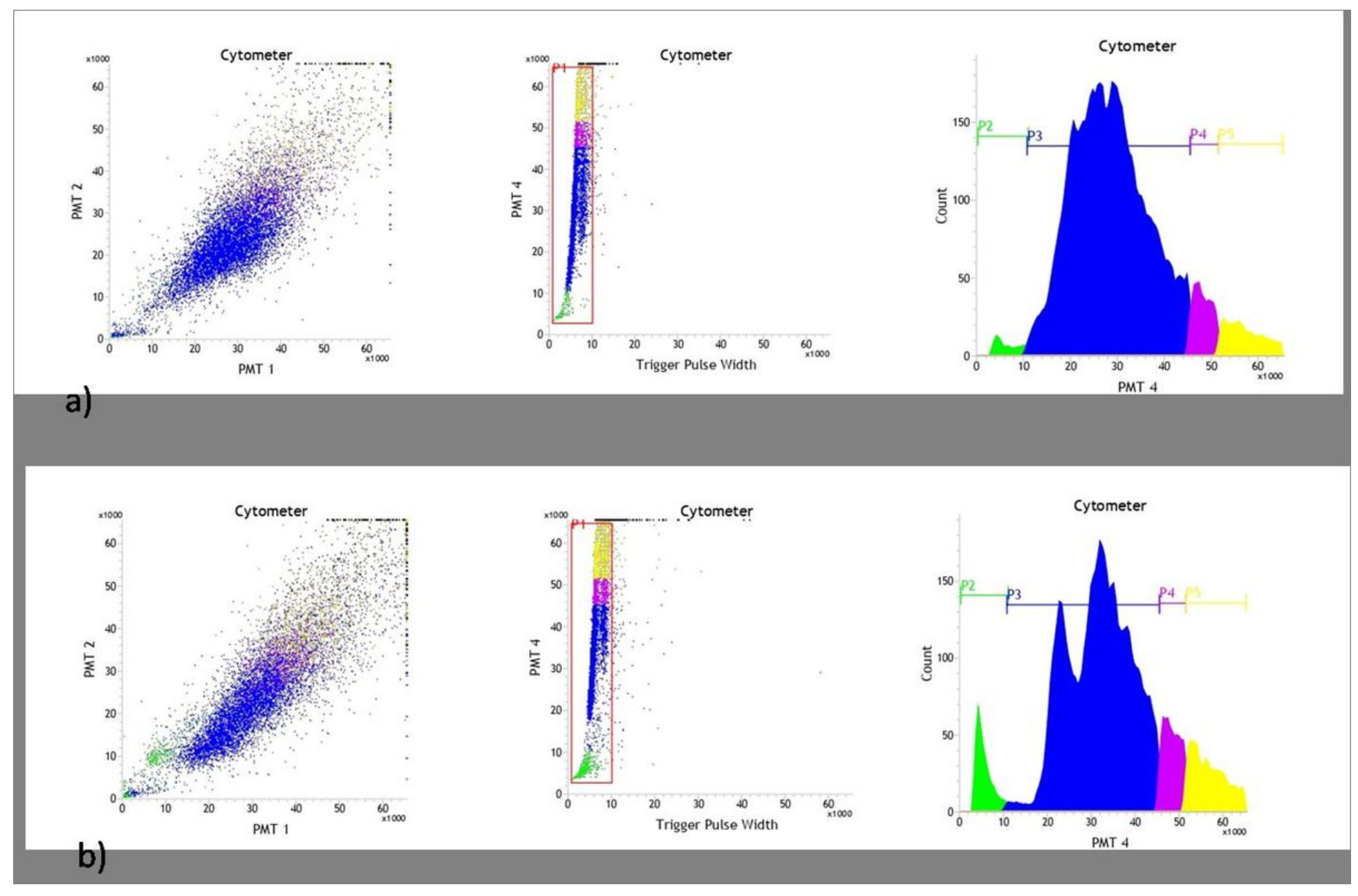

Figure 10

MCF7 cell lines were treated with IC50 concentration of compounds. a) Control treated with IC50 concentration of compound increased the percentage of apoptosis in G0-G1 phase (1.39\%), b) MCF7 cells treated with IC50 concentration of compound increased the percentage of apoptosis in G0-G1 phase (5.16\%). The result indicates that apoptosis was induced in MCF7 cells by Pg-AgCINPs in a dosedependent manner. 


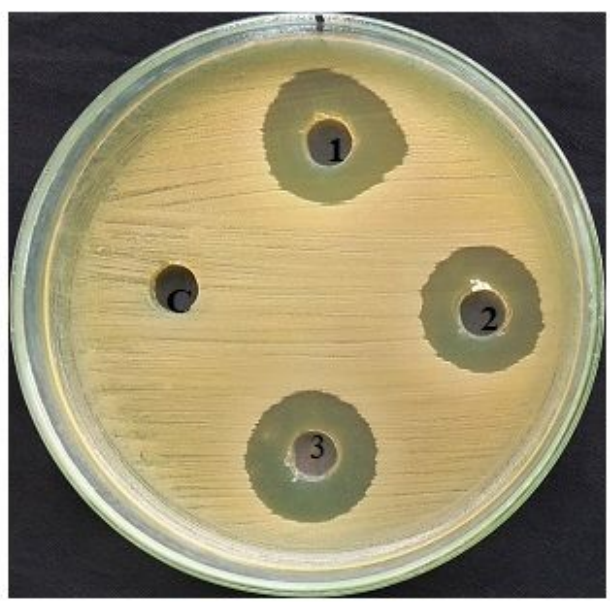

MRSA

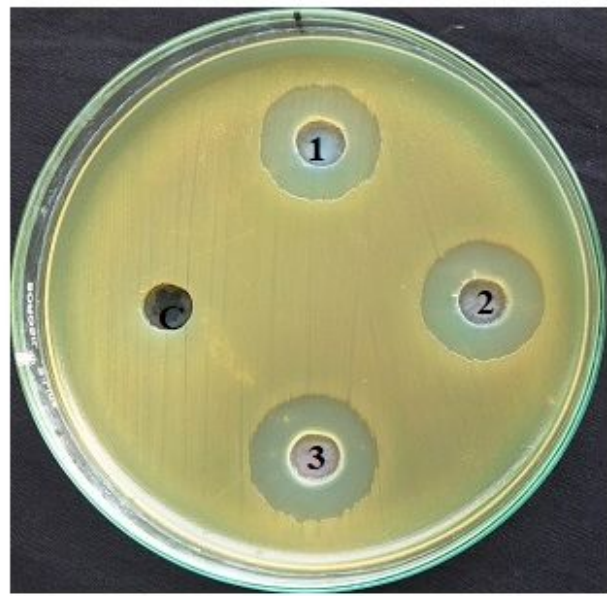

P. aeruginosa

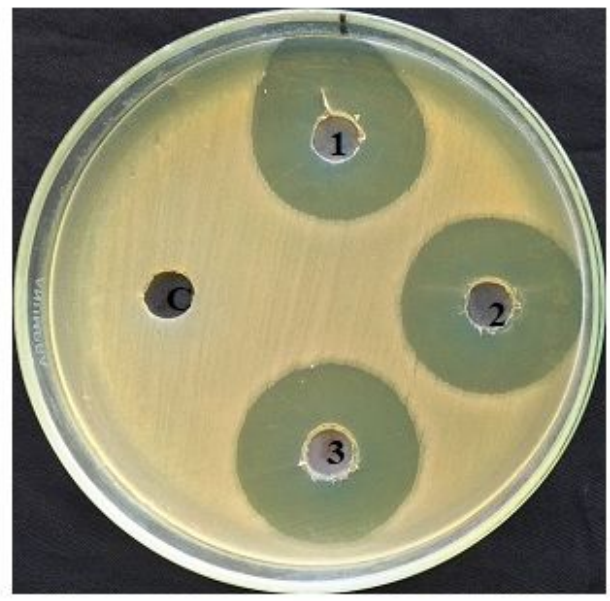

C. albicans

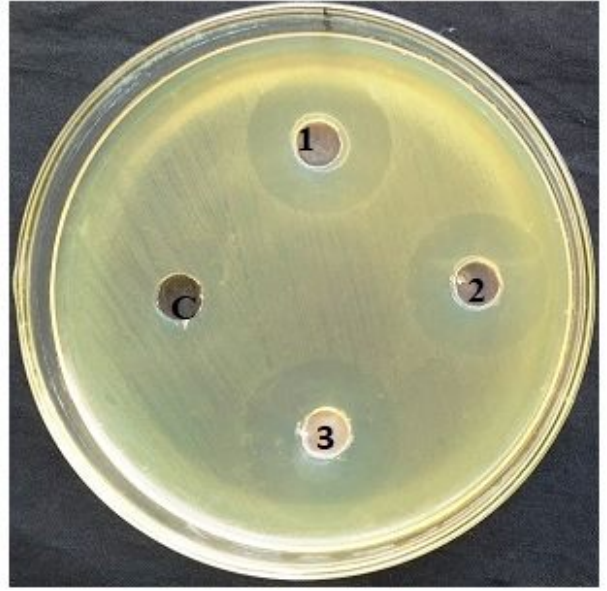

VREF

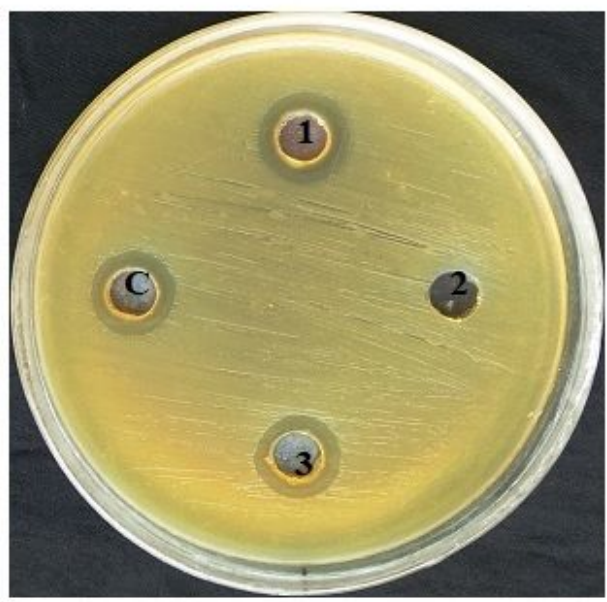

E. coli

1- $1 \mathrm{mg} / \mathrm{mL} \mathrm{Pg-AgClNPs}$

2- $2 \mathrm{mg} / \mathrm{mL} P g$-AgClNPs

3- $3 \mathrm{mg} / \mathrm{mL} \mathrm{Pg-AgClNPs}$

C- Control

\section{Figure 11}

Zone of inhibition of Pg-AgCINPs against human bacterial and fungal pathogens of clinical isolates. 


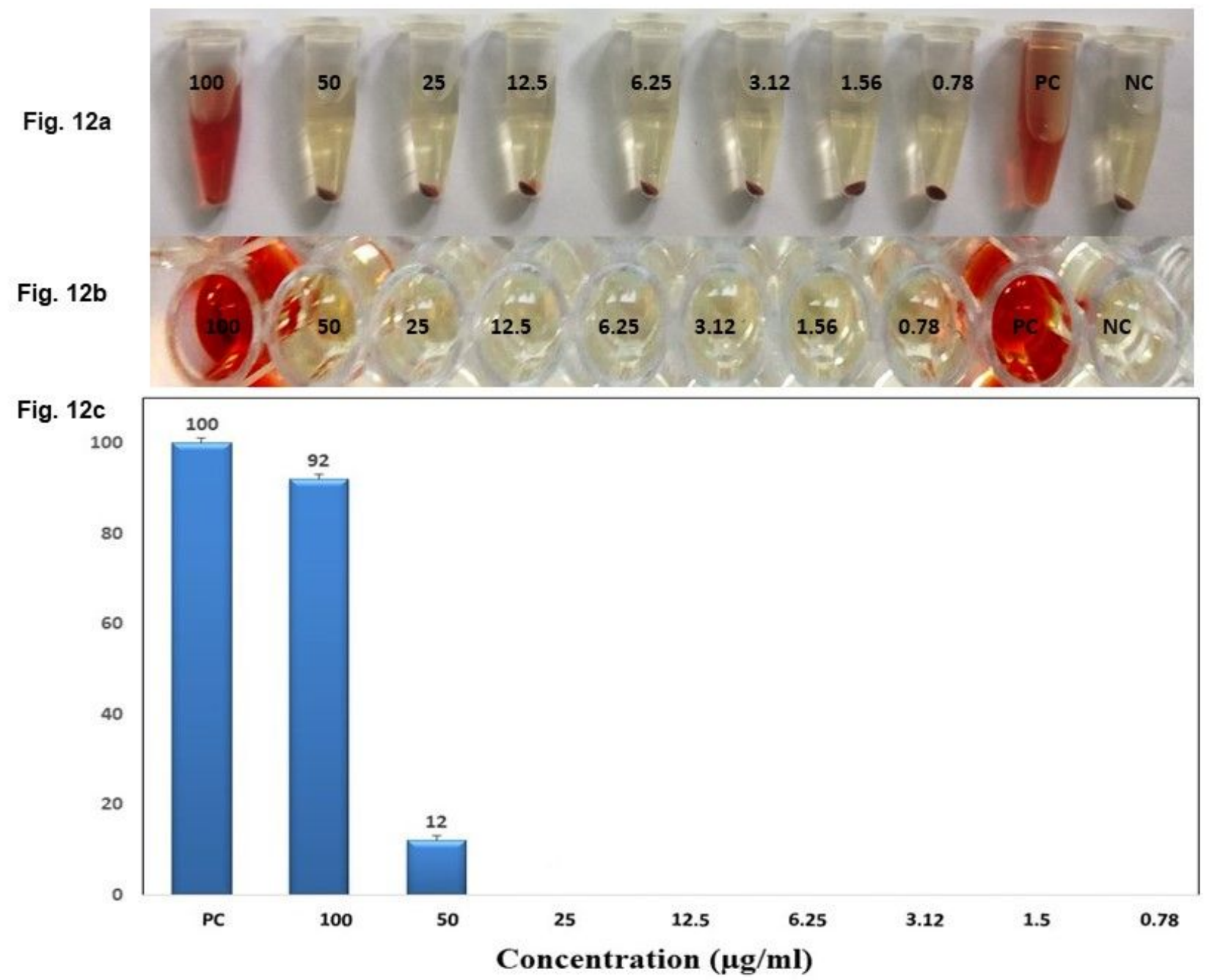

Figure 12

$(a, b, c)$ : Hemolytic activity of Pg-AgCINPs treated against human O(+ve) RBCs. 


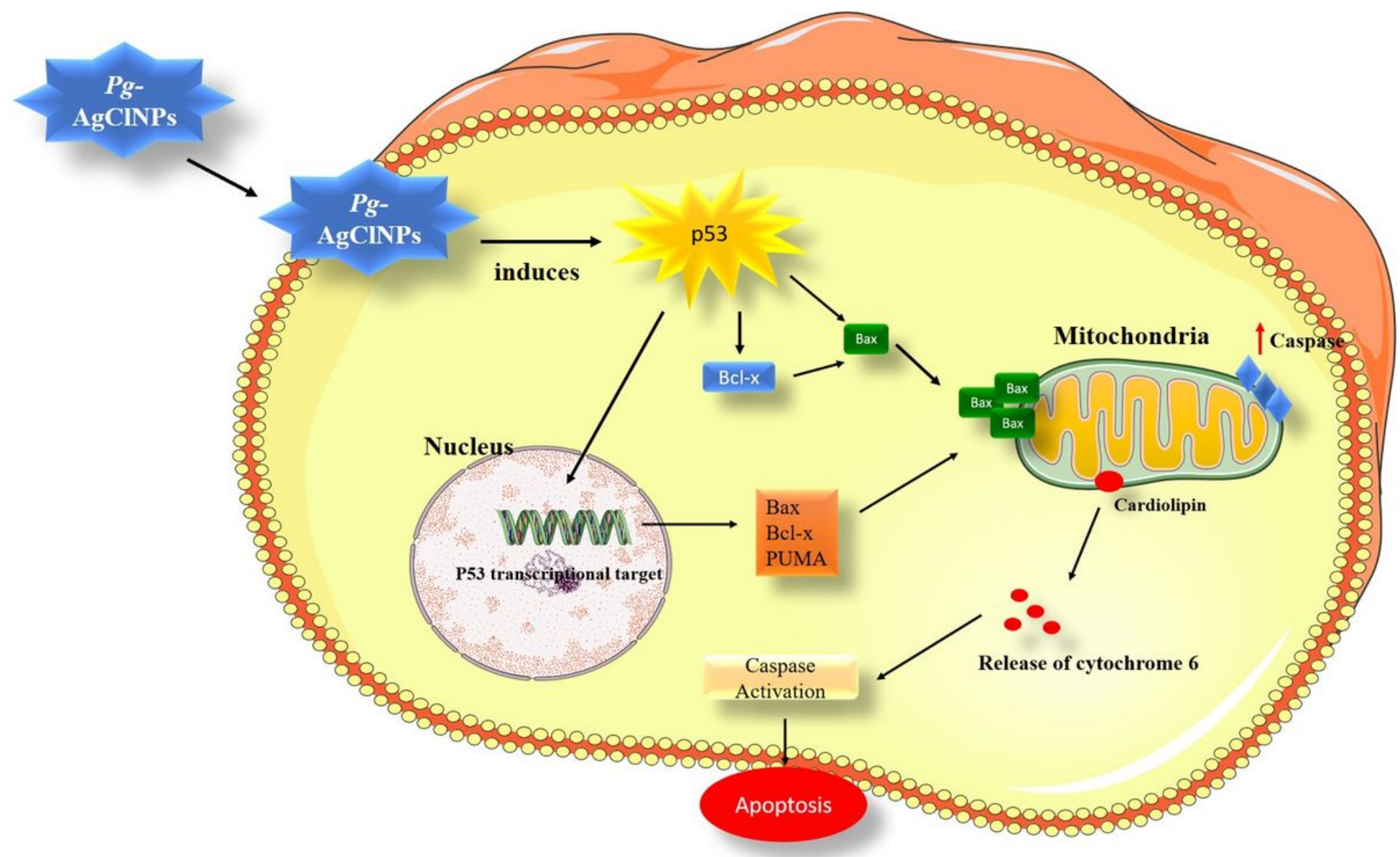

Figure 13

Pg-AgCINPs action illustrating the possible mechanism of the delivery system of noncombinations induced by anti-cancer activity

\section{Supplementary Files}

This is a list of supplementary files associated with this preprint. Click to download.

- GraphicalAbstract.jpg 